\title{
The Effect of Sustainability Report and Profitability on Company Value: Evidence from Indonesian Sharia Shares
}

\author{
Mita Kurnia Rizki \\ Universitas Islam Negeri (UIN) Walisongo Semarang \\ email: mitakurniarizki@gmail.com
}

\author{
Ratno Agriyanto \\ Universitas Islam Negeri (UIN) Walisongo Semarang \\ email: ratnoagriyanto@walisongo.ac.id

\section{Dessy Noor Farida} \\ Universitas Islam Negeri (UIN) Walisongo Semarang \\ email: dessy_nf@walisongo.ac.id
}

\begin{abstract}
The purpose of this research is to determine the effect of sustainability report disclosure and profitability on firm value. Type of this research uses a quantitative method with multiple linear regression of the data analysis techniques. The data used in this research are secondary data. The population of research companies are listed on the Indonesia Sharia Stock Index (ISSI) as of December 29, 2017. The sample used purposive sampling method on 13 company samples. The results of this research indicate that sustainability report does not affect firm value and profitability affects firm value. This study implies that regulators should encourage companies to disclose sustainability reports because there are still a few companies that disclose it. Regulators are also expected to participate in providing socialization so that investors understand the meaning of the sustainability report.
\end{abstract}

Keywords: Sustainability Report; Profitability; Firm Value

\begin{abstract}
Abstrak: Tujuan dari penelitian ini adalah untuk mengetahui pengaruh laporan keberlanjutan dan profitabilitas terhadap nilai perusahaan. Penelitian ini menggunakan metode kuantitatif dengan regresi linier berganda. Data dalam penelitian ini adalah data sekunder. Populasi perusahaan penelitian terdaftar di Indeks Saham Syariah Indonesia (ISSI) pada tanggal 29 Desember 2017. Sampel menggunakan metode purposive sampling pada 13 perusahaan. Hasil penelitian menunjukkan bahwa laporan keberlanjutan tidak berpengaruh terhadap nilai perusahaan dan profitabilitas berpengaruh terhadap nilai perusahaan. Studi ini menyiratkan bahwa regulator harus mendorong perusahaan untuk mengungkapkan laporan keberlanjutan karena masih ada beberapa perusahaan yang mengungkapkannya. Regulator juga diharapkan untuk berpartisipasi dalam memberikan sosialisasi sehingga investor memahami arti dari laporan keberlanjutan.
\end{abstract}

Kata Kunci: Laporan Keberlanjutan; Profitabilitas; Nilai Perusahaan

Economica: Jurnal Ekonomi Islam - Volume 10, Nomor 1 (2019) 


\section{Introduction}

The development of business in an increasingly competitive era of globalization has encouraged companies to be able to compete at the national and international levels and increase the value of the company. The value of the company can be reflected in the stock price, the higher the stock price, the higher the value of a company. The increasing value of a company can have a good impact because it can improve the welfare of the company owner (Nurhayati 2013).

Company profitability is one of the factors that can influence company value. Company profitability in good condition will have a positive impact on the decision of investors to invest, and will have an impact on the decision of creditors in connection with the financing of the company through debt (Harmono 2015). Companies are competing to increase profitability by exploiting natural resources, so the company does not pay attention to the impacts that will be caused. In addition to the level of profitability, social, economic, and corporate environment are also considerations of investors to buy shares of a company (Putri and Christiawan 2014).

Law No 40 of 2007 states that companies whose business activities are related to natural resources are required to be socially and environmentally responsible. Article 1 paragraph 3 states that social and environmental responsibility is the company's commitment to participate in sustainable economic development in order to improve the quality of life and the environment that is beneficial, both for the company itself, the local community, and society in general.

Social, economic and environmental responsibilities can be disclosed through the sustainability report. Elkington's sustainability report is a report that contains not only financial performance information but also nonfinancial information consisting of information on social and environmental activities that allow company to grow on an ongoing 
The Effect of Sustainability Report and Profitability on Company Value ...

basis (sustainable performance) (Tarigan et al, 2014). Sustainability report is a description of company activities in sustainable development.

Based on data from the Financial Services Authority, until the end of 2016 the number of Financial Services Institutions (FSI) and company listing on the Indonesia Stock Exchange (IDX) as much as 9\% has revealed sustainability reports, $91 \%$ of the rest have not revealed. From these data, it can be seen that there are still a few LJK and Issuers that disclose the sustainability report, because sustainability report are still voluntary. But the actual sustainability report is a social responsibility to stakeholders that is important to disclose.

Research on sustainability report, profitability and company value find mixed results. Profitability has a significant positive effect on firm value, while sustainability report does not have a significant effect on firm value (Marwa, et al, 2017). Research by Tedy Kurniawan et al. states that disclosure of economic category sustainability reports has a positive effect on the value of companies in Indonesia and in Singapore, disclosure of environmental category sustainability reports has a negative effect on the value of companies in Indonesia and Singapore, while disclosure of social category sustainability report does not affect firm value in Indonesia and Singapore (Kurniawan, et al, 2018).

This research was conducted based on previous research with several differences that are variables measuring the value of the company using the Price to Book Value (PBV) ratio. The advantages of PBV include book value that provides a relatively stable value, the ratio can be compared among similar companies to see undervaluation or overvaluation, and companies that have negative income can be assessed using PBV ratios (Ribca 2009). The variables that measure the profitability of using a measuring instrument Earning Per Share (EPS) as well as the research object are registered companies in Indonesia Sharia Stock Index (ISSI) year study period 2013-2017.

Economica: Jurnal Ekonomi Islam - Volume 10, Nomor 1 (2019) 


\section{Literature Review}

\section{Signaling Theory}

Signaling theory was first developed by Ross (1977). According to Ross, signaling theory is that if the company is in a good condition, then the executive will be compelled to convey the information to prospective investors to be interested in investing their funds into the company's shares (Ross, 1977). Signaling theory has several main elements involved, namely (Connelly and Ireland 2011):

a. A signaler is a party that obtains positive and negative information about individuals, products, or organizations that are useful to outsiders.

b. Signal is information that is positive or negative. Signaling theory focuses on communication that has positive information in an effort to convey good organizational conditions.

c. Receiver is an outsider who receives information from the organization.

\section{The Value of The Company}

Company value is the price of a stock that has circulated in the stock market that must be paid by investors to be able to have a public company. The value of the company is reflected in the strength of the bargaining stock. If the company is estimated as a company that has good prospects in the future, the value of the stock will be high. Conversely, if the company is considered to have less prospects, then the stock price becomes weak (Ferina and Tjandrakirana 2015).

The value of the company has some indicators such as:

a. Price Earning Ratio (PER) is a ratio that compares prices equal to income per stock. Investors will buy a company stock with a small 
PER, because a small PER illustrates a fairly high net income and at a fairly low price (Mulyani and Pitaloka 2017).

b. Tobin's $Q$ is a ratio that shows the current estimate of the financial market on the value of returning every rupiah of additional investment. If the q-ratio is above one, it indicates that investment in assets generates profits that give a higher value than investment expenditure. If the q-ratio is below one, investment in assets is not attractive (Sabrin et al. 2016).

c. Price to Book Value (PBV) is a ratio that compares the price of a stock market with the stock price based on the price of a book. In this study the value of the company is proxied using PBV. The use of PBV has advantages such as: (1) Producing values that are relatively stable and can be compared with market prices; (2) provide consistent accounting standards for all companies; (3) Companies that cannot be measured by PER because of negative income, can be evaluated using PBV (Widyantari and Yadnya 2017).

\section{Profitability}

Profitability ratio is a ratio to assess a company's ability to earn profits. This ratio provides a measure of the effectiveness of a company in managing its assets and capital so as to generate profits. The level of company profitability can be seen by ratio analysis. There are several types of profitability ratios that can be used, including (Kasmir 2008):

a. Profit Margin on Sales is a ratio used to measure profit margin against sales.

b. Return on Investment (ROI) or return on total assets is the ratio that measures the company's ability to utilize the amount of assets to generate earnings.

Economica: Jurnal Ekonomi Islam - Volume 10, Nomor 1 (2019) 
c. Return on Equity (ROE) is a ratio that measures company efficiency in using its own capital to generate profits.

d. Earning Per Share shows profit earned per share. This ratio is obtained by dividing the net income obtained in a certain period with the total number of shares outstanding during the same period of time or calculated by dividing income after interest, depreciation and tax with the total number of shares outstanding (Velankar, Chandani, and Ahuja 2017). In this study, profitability is measured by the Earning Per Share ratio. Earning Per Share is a metric that is often used as a barometer to measure a company's profitability in achieving profits for shareholders. Thus, earnings per share is the main driver of stock prices so that it can affect the value of the company (Islam et al. 2014).

\section{Sustainability Report}

Sustainability report is reporting by companies or organizations about the economic, environmental and social impacts caused by their daily activities (Sutopo et al. 2018). The triple bottom line was initiated by John Elkington, often called 3P (Profit, People and Planet). The triple bottom line helps organizations not only look at the economic value they produce, but also allows to include environmental and social values that can be added or reduced in assessing their performance (Zak 2015).

Sustainability report has several functions that are, for companies, as a tool for measuring achievement of employment targets in the issue of the Triple Bottom Line; for investors, sustainability report becomes a control tool for the achievement of company performance and as a medium for investors' consideration in allocating their financial resources. While for other stakeholders (media, government, consumers, academics and others) sustainability report is a benchmark to assess the seriousness of the 
company's commitment to sustainable development (Manisa, Defung, and Global 2017).

\section{Hypothesis Development}

\section{Effect of Sustainability Report on Company Values}

Sustainability report is a report that reveals economic, social and environmental performance. Sustainability report is as a form of corporate responsibility towards stakeholders. Reports on economic, social and environmental performance can attract investors to invest their funds in a company. The company's liability for securities that occur as a result of its business activities can affect the value of the company.

Lawrence Loh et al.'s research state that sustainability report has a significant positive effect on the company and the better the quality of sustainability report, the stronger the linkage (Loh, et al, 2017). The results of research conducted by Rahmawati et al., 2018 also stated that the sustainability report had a positive effect on the value of the company, both in Indonesia and Singapore. While the research conducted by Swarnapali et al, 2018 has also proven that sustainability report has a positive effect on firm value. When a company engages in socially commendable behavior, people's perceptions of the company will be far more profitable, resulting in the company being valued in the capital market. The higher the sustainability report index, the higher the value of the company. Based on the description, the first hypothesis in this study is:

\section{$\mathrm{H}_{1} \quad$ : Sustainability Report has a positive effect on company value Effect of Profitability on Company Values}

Profit is one of the most noticed factors by investors before investing their funds, because from earnings information, the welfare of the capital owners can be reflected later. The company's ability to earn profits can be

Economica: Jurnal Ekonomi Islam - Volume 10, Nomor 1 (2019) 
measured using profitability ratios. Profitability is a tool for considering investors in making investments, so that profitability can affect the value of the company.

Research by Sabrin et al. states that profitability has an effect on company value because the value of the company has a positive sentiment towards achieving profit for payment of dividends. Stock prices will increase because the company shows a positive signal to pay dividends (Sabrin et al. 2016). The results of the research conducted by Habibi and Andraeny (2018) state that profitability has a significant positive effect on firm value. The same results are also shown by Sarita, et al., 2016 which states that profitability affects firm value because the value of the company has a positive sentiment towards achieving a profit for payment of dividends. Stock prices will increase because the company shows a positive signal to pay dividends. The higher the profitability ratio, the higher the value of the company. Based on the description, the second hypothesis in this study is:

\section{$\mathrm{H}_{2} \quad$ : Profitability has a positive effect on company value}

Based on literature review and hypothesis formulation, the research model is presented in Figure 1.

Figure 1. Research model

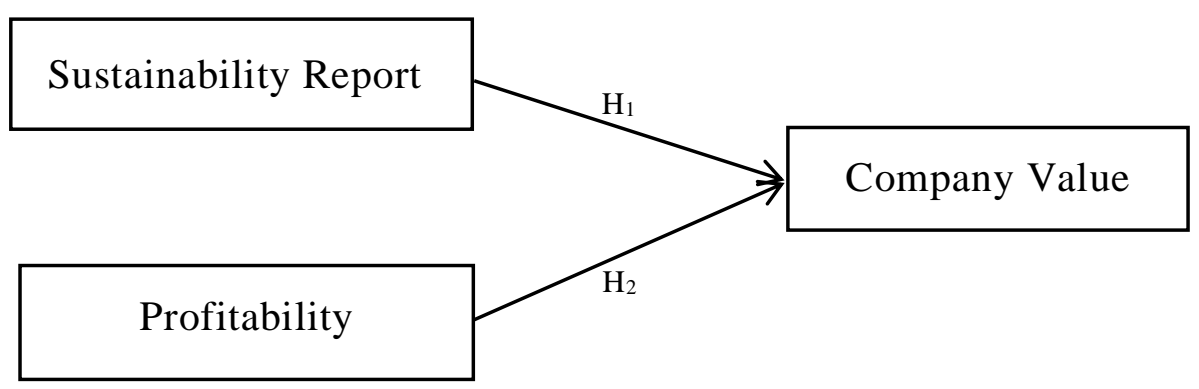


The Effect of Sustainability Report and Profitability on Company Value ...

\section{Methods}

\section{Types and Data Sources}

This type of research uses a quantitative research method with multiple linear regression data analysis techniques. The data used in this research are secondary data. The secondary data are in the form of sustainability report and annual report in 2013 - 2017 from companies listed on the Indonesian Syariah Stock Index (ISSI) as of December 29, 2017. While the data sources of this research are the sustainability report and annual report that have been published and accessed through the websites of each company.

\section{Population and Samples}

The population of this study are companies listed on the Indonesian Syariah Stock Index (ISSI) as of December 29, 2017. The number of companies listed on the ISSI as of December 29, 2017 is 365 companies.

The selection of samples uses non-probability sampling technique with purposive sampling method, which is the selection of samples based on certain criteria. The criteria specified are as follows:

1. Company that listed and registered in ISSI of December 29, 2017.

2. Companies that issue annual reports in 2013 - 2017.

3. Companies that consistently publish sustainability reports in 20132017.

The sampling using the purposive sampling method carried out as in table 1:

Economica: Jurnal Ekonomi Islam - Volume 10, Nomor 1 (2019) 
Mita Kurnia Rizki, Ratno Agriyanto, Dessy Noor Farida

Table 1. Sampling Procedures and Criteria

\begin{tabular}{lc}
\hline Information & Total \\
\hline Companies listed on the ISSI in 2017 & 365 \\
\hline Companies that do not have a complete annual report in 2013 - 2017 & $(0)$ \\
\hline Companies that have never published a sustainability report & $(344)$ \\
\hline Companies that have not consistently issued sustainability reports during & $(8)$ \\
$2013-2017$ & \\
\hline Number of companies sampled & 13 \\
\hline Number of Observation Data $(13 \times 5)$ & 65 \\
\hline
\end{tabular}

Descriptive Research Variables

Descriptive Corporate Value Variables

Figure 2. Average company value

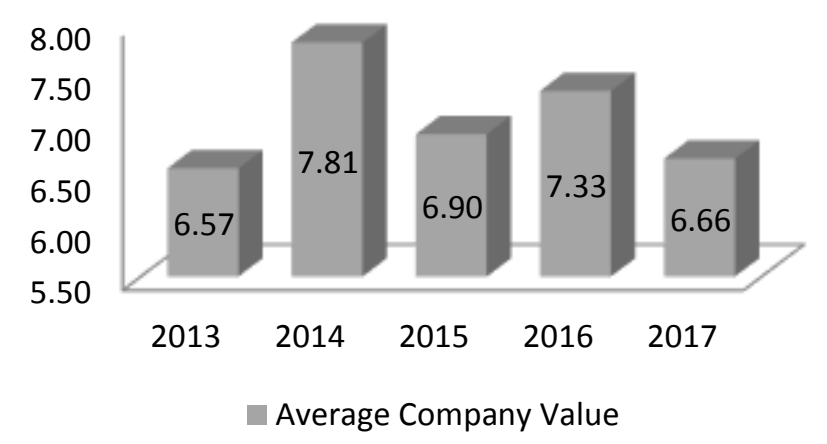

The graph above shows the average value of the company in 2013 to 2017. The company's value is measured using price to book value. In 2013, the average value of the company was 6.57. In 2014 it showed that the 
company value increased by 1.24 compared to 2013. In 2015 showed that the average value decreased by 0.91 compared to 2014. In 2016 shows the average value of the company amounting increased by 0.43 compared to 2015. In 2017 the average value of the company amounted to 6.66 decreased by 0.67 compared to the year 2016. Companies that consistently have company value above average is Uniliver Indonesia Tbk since its value is almost 10 times higher than other companies. So that the average value of the company also increases.

The average sustainability report chart, profitability and company value can help investors to know Islamic stocks that have high profitability but still have economic, social and environmental responsibility. The graph shows interesting results. Aneka Tambang (Persero) Tbk consistently discloses the sustainability report above average disclosure index, but the company is consistent under the average profitability and company value. Astra International Tbk consistently has profitability above average, but is consistently below the average sustainability report disclosure index and company value. Uniliver Indonesia Tbk consistently has company value and profitability above average, but disclosure of sustainability report has fluctuated.

Ten other companies experienced fluctuations in the average sustainability report disclosure, profitability and company value. The relationship of influence between the sustainability report variable, profitability and firm value will be empirically tested by multiple linear regression to find out the real results of the influence of the three variables. 


\section{Descriptive Variable of Sustainability Report}

Figure 3. Average sustainability report disclosure index

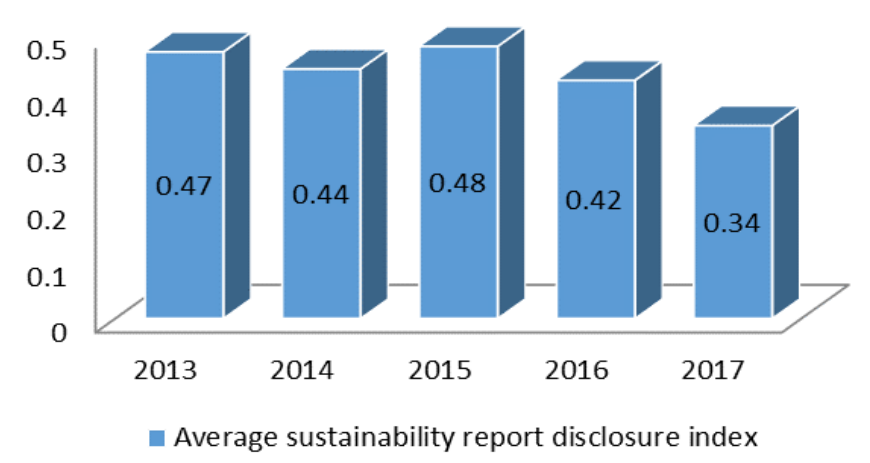

The graph of the data above (see figure 3) is the result of the average sustainability report index of 13 companies each year. The sustainability report index is obtained through the calculation of the total disclosure score that is fulfilled divided by the maximum number of scores. In 2013 the average index was $47 \%$ of the indicators disclosed in the sustainability report. Companies that disclose the sustainability report above the average are Aneka Tambang (Persero) Tbk, XL Axiatama Tbk, Vale Indonesia Tbk, National Gas Company (Persero) Tbk, Bukit Asam Tbk, and Semen Indonesia (Persero) Tbk. In 2014 the average index down 3\% from the previous year which was $47 \%$. Companies that disclose the sustainability report above average are Aneka Tambang (Persero) Tbk, Vale Indonesia Tbk, Perusahaan Gas Negara (Persero) Tbk, Semen Indonesia (Persero) Tbk, Total Bangun Persada Tbk, United Tractors Tbk, Uniliver Indonesia Tbk, and Wijaya Karya (Persero) Tbk.

In 2015, the sustainability report disclosure index was 48\%, this number increased by $4 \%$ compared to 2014. Companies that disclose the sustainability report above average are AKR Corporindo Tbk, Aneka 
Tambang (Persero) Tbk, Vale Indonesia Tbk, The National Gas Company (Persero) Tbk, Bukit Asam Tbk, and Total Bangun Persada Tbk. In 2016, the average sustainability report disclosure index was $6 \%$ lower compared to 2015. The companies that disclose sustainability report above average are AKR Corporindo Tbk, Aneka Tambang (Persero) Tbk, XL Axiatama Tbk, Bukit Asam Tbk, Total Bangun Persada Tbk and United Tractors Tbk.

In 2017 the sustainability report disclosure average was 34\%, lower by 8\% compared to 2016. The companies that disclosed the sustainability report above average are Aneka Tambang (Persero) Tbk, Bukit Asam Tbk, Total Bangun Persada Tbk and United Tractors Tbk. The sustainability report disclosure in 2013 to 2017 shows that the disclosure in five years is not more than 50\%. These results are very low and only Aneka Tambang Tbk can consistently disclose the sustainability report above average in a fiveyear period, while Astra International Tbk and Indika Energy Tbk have an index below average and the remaining companies experience fluctuations.

\section{Descriptive Variable Profitability}

Figure 4 show that profitability in this study is measured using Earnings Per Share, so the unit used is rupiah. In 2013, the average profitability was 386.09. Companies that have profitability above average are Astra International Tbk, National Gas Company (Persero) Tbk, Bukit Asam Tbk, Semen Indonesia (Persero) Tbk, United Tractors Tbk and Uniliver Indonesia Tbk. 2014 showed an average profitability greater than 15.48 from 2013. Companies that have profitability above average are Astra International Tbk, Bukit Asam Tbk, Semen Indonesia (Persero) Tbk, United Tractors Tbk, and Uniliver Indonesia Tbk.

Economica: Jurnal Ekonomi Islam - Volume 10, Nomor 1 (2019) http://journal.walisongo.ac.id/index.php/economica 
Figure 4. Average profitability

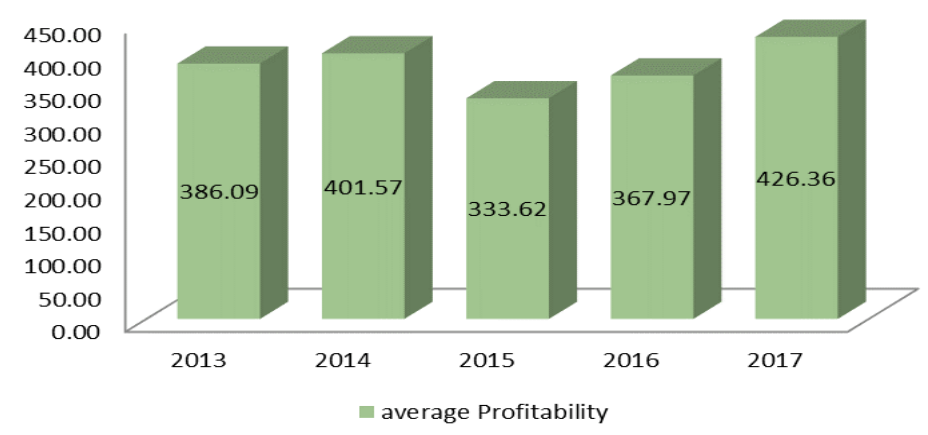

In 2015, the average profitability decreased by 67.95 compared to profitability in 2014. Companies that have profitability above average are Astra International Tbk, Bukit Asam Tbk, Semen Indonesia (Persero) Tbk, United Tractors Tbk and Uniliver Indonesia Tbk. In 2016, the average profitability increased by 34.35 compared to the average profitability in 2015. Companies that have profitability above the average are Astra International Tbk, Bukit Asam Tbk, Semen Indonesia (Persero) Tbk, United Tractors Tbk and Uniliver Indonesia Tbk.

In 2017 shows an average profitability an increase of 58.39 compared to the average profitability in 2016. Companies that have an average profitability are Astra International Tbk, Indika Energy Tbk, United Tractors Tbk and Uniliver Indonesia Tbk. The average profitability from 2013 to 2017 shows that only in 2015 there was a decline. Companies that consistently have profitability above average are Astra International Tbk, Bukit Asam Tbk, United Tractors Tbk and Uniliver Indonesia Tbk. Companies that consistently have profitability below the average, namely AKR Corporindo Tbk, Aneka Tambang Tbk, XL Axiata Tbk, Vale Indonesia Tbk, Total Bangun Persada Tbk and Wijaya Karya (Persero) Tbk. 


\section{Operational Definition of Research Variables}

\section{The Value of The Company}

The value of the company in this study is proxied by the Price to Book Value (PBV) ratio (Mindra and Erawati 2014). PBV ratio is the ratio of stock market prices to book value of shares.

PBV calculation formula is:

$$
P B V=\frac{\text { Market Price Per Share }}{\text { Book Value Per Share }}
$$

\section{Sustainability Report}

The sustainability report in this study is measured using the Sustainability Report Disclosure Index (SRDI), includes these following themes : General standards consist of disclosure of strategy and analysis, organizational profile, identified material and boundary aspects, stakeholder relations, report profiles, governance, ethics, and integrity. While special standards contain disclosures of management approaches, indicators of economic categories, indicators of environmental categories, and indicators of social categories. (GRI-G4 Guideliness). SRDI calculation is done by giving a score of 1 if the item is disclosed, and a score of 0 if the item is not disclosed, then the score is summed so as to get the score of each company. The sustainability report calculation formula is:

$$
S R D I=\frac{\text { Total disclosure score fulfilled }}{\text { Maximum score }}
$$

\section{Profitability}

Profitability shows the company's ability to generate profits. Profitability in this study is measured by Earning Per 
Share (EPS) (Hasibuan and Ar 2015). EPS is the profit ratio divided by the number of shares. The EPS calculation formula is:

$$
E P S=\frac{\text { Net income after interest and tax cost }}{\text { Outstanding Shares }}
$$

\section{Data analysis technique}

Data analysis used in this study is multiple regression analysis to examine the effect of sustainability report and profitability on firm value. The analysis model of this study is described as follows:

$$
\mathrm{NP}_{\mathrm{t}+1}: \alpha+b_{1} \mathrm{SRDI}_{\mathrm{t}+0}+b_{2} \mathrm{PF}_{\mathrm{t}+0}+\varepsilon
$$

Information:

$\begin{array}{ll}\text { A } & : \text { Constant } \\ b_{1}-b_{2} & : \text { Regression coefficient } \\ \text { NP } & : \text { The value of the company } \\ \text { SRDI } & : \text { Sustainability Report Disclosure Index } \\ \text { PF } & : \text { Profitability } \\ \varepsilon & : \text { Error Standard }\end{array}$

\section{Results and Discussion}

\section{Model Feasibility Test (Classical Assumption Test)}

The regression model will be declared good and can be done if it meets the classic assumption test, namely the normality test, multicollinearity test, autocorrelation test and heterosociality test. The regression model is not normally distributed, so it requires screening and transformation of data which result to data reduction by 9 data. The regression model is autocorrelated so that the data have to be transformed to avoid autocorrelation. And this study has fulfilled the classic assumption test, as shown in the table 2 and table 3 : 
The Effect of Sustainability Report and Profitability on Company Value ...

Table 2. Summary of Classical Assumption Tests for Hypothesis Testing Effect of Sustainability Report and Profitability on Company Values

\begin{tabular}{lll}
\hline Independent Variable & & \\
\hline Multikolonierity Test & Tolerance & VIF \\
\hline Sustainability Report & 1.000 & 1.000 \\
Profitability & 1.000 & 1.000 \\
\hline Heteroskedastisity Test (Glejser test) & Sig.t-test & \\
\hline Sustainability Report & 0,633 & \\
Profitability & 0,095 & \\
\hline Durbin-Watson test & 1,636 & \\
\hline Normality Residual Test & & \\
\hline kolmogorov- Smirnov test & 0,200 & \\
\hline $\mathrm{N}=65$ & & \\
\hline
\end{tabular}

Source: secondary data processed (2019)

Table 3. Summary of Hypothesis Testing Effect of Sustainability Report and Profitability on Company Values

\begin{tabular}{lcrc}
\hline Independent Variable & & & \\
\hline Hyphothesis Test & Coefficient & t value & \multicolumn{1}{c}{ Sign } \\
\hline Constant & 0,282 & 0,945 & 0,349 \\
Sustainability Report & 0,309 & 1,419 & 0,162 \\
Profitability & 0,135 & 3,200 & 0,002 \\
\hline R square & 0,204 & & \\
Adjusted R square & 0,171 & & \\
F statistic & 6,158 & & \\
Sig F statistic & 0,004 & & \\
\hline Dependent variable: Firm Value & & & \\
N = 65 & & & \\
$*$ *) significant level 5\% & & & \\
\hline
\end{tabular}

Source: secondary data processed (2019)

Economica: Jurnal Ekonomi Islam - Volume 10, Nomor 1 (2019) 


\section{The Effect of Sustainability Report on Company Value}

The first hypothesis of the study which states that sustainability report has a positive effect on corporate values is rejected, because based on the tests that have been carried out, the sustainability report variable does not have a significant effect on firm value.

The results of this study are in line with the research of Sejati and Prastiwi (2015) which states that sustainability report is not significant in influencing company value. The cause of the insignificance of the effect of sustainability report on the value of the company is made possible by investors in Indonesia who are more interested in the shares of the company that have expected profits without regard to disclosure of sustainability report (Sejati and Prastiwi 2015).

The results of this study show the same results as the results of Marwa et al., (2017) study which states that the sustainability report variable has no influence on company value. It is because there are additional costs and efforts in making sustainability reports and disclosures that are still voluntary so that the issuers do not yet need to make related reports.

Sustainability report functions as a signal given by the company to investors that the company has economic, environmental and social responsibility. Companies that have carried out economic, environmental and social responsibilities have not become a signal for investors to make investment decisions. Sustainability report still gets less attention and has not been well received by investors. The results of the study have not provided support for signaling theory. This study proves that sustainability report disclosures have not been proven to increase the value of the company on the stock exchange. Unfortunately, investors in Indonesia do not have a positive assessment of the company that has disclosed the sustainability report. 
The Effect of Sustainability Report and Profitability on Company Value ...

\section{Effect of Profitability on Company Value}

The second hypothesis of the study which states that profitability has a positive effect on firm value is accepted, because based on the tests that have been carried out the profitability variable measured using earnings per share has a significant effect on firm value. It is evidenced by the significance value of $0.002<0,05$ (below 5\%).

The results of this study are in line with the research of Suparno and Ristika (2017) which states that earnings per share has a significant positive effect on firm value. Either large or small earnings per share can determine the value of the company. The high earnings per share values indicates good performance and may demonstrate the company's prospects in the future (Suparno and Ramadini 2017).

The results of this study show the same results with the research of Ekaprastyana, D., \& Anwar (2017) which states that earnings per share has a significant positive effect on firm value.Good profitability will encourage companies to pay high dividends. Therefore, earnings per share will give a positive signal to investors so that it can influence investors' decisions to buy shares and increase the value of the company (Ekaprastyana, D., \& Anwar 2017).

Companies registered in the ISSI have reported to the public about achieving profitability. Publication of financial statements is a signal given by the company to investors. The company performance signal is expected to be useful for investors to make investment decisions. This study proves that profitability measured using earnings per share can increase company value. The results of the study support signaling theory that is profitability has succeeded in giving signals to investors. Investors will react to company profitability information. The higher the company's profitability, the higher the company's value in the eyes of investors.

Economica: Jurnal Ekonomi Islam - Volume 10, Nomor 1 (2019) 


\section{Conclusion}

This study provides empirical evidence that sustainability report does not significantly influence company value. Sustainability reports function as signals given by the company to investors that the company has reported economic, environmental and social accountability. The results of the study have not provided support for signaling theory. This study proves that sustainability report disclosures have not been proven to increase the value of the company on the stock exchange.

Profitability has a significant effect on firm value. Companies registered in the ISSI have reported to the public about achieving profitability. Publication of financial statements is a signal given by the company to investors. This study proves that profitability measured using earnings per share can increase company value. The results of the study support signaling theory that is profitability has succeeded in giving signals to investors. Sustainability report and profitability together have a significant effect on company value. If the two independent variables increase or decrease together, the dependent variable will follow in the same direction.

The limitation in this study is that not all samples were included in the study, because there were 5 outlier data. Another limitation in this study is only testing the profitability and sustainability report variables on the value of the company for 5 years. It would be better if in the next study to add years of research to empirically test signalling theory.

\section{References}

Connelly, Brian, and R Duane Ireland. 2011. "Signaling Theory: A Review and Assessment," no.

January. https://doi.org/10.1177/0149206310388419.

Ekaprastyana, D., \& Anwar, S. 2017. "The Effect of Earning Per Share and Debt to Asset Ratio on Firm's Value: Case Study on Food and Beverage 
Corporation Listed in Indonesia Stock Exchange." Jurnal Keuangan Dan Perbankan 13 (2): 120-27.

Ferina, I.S, and Rina Tjandrakirana. 2015. "PENGARUH KEBIJAKAN DIVIDEN, KEBIJAKAN HUTANG, DAN PROFITABILITAS TERHADAP NILAI PERUSAHAAN (Studi Pada Perusahaan Pertambangan Yang Terdaftar Di BEI Periode 2009-2013)." Jurnal Akuntanika 2 (1): 52-66.

Harmono. 2015. Manajemen Keuangan Berbasis Balanced Scorecard Pendekatan Teori, Kasus Dan Riset Bisnis. 1st ed. Jakarta: Bumi Aksara.

Hasibuan, Veronica, and Moch Dzulkirom Ar. 2015. "PENGARUH LEVERAGE DAN PROFITABILITAS TERHADAP NILAI PERUSAHAAN ( Studi Pada Perusahaan Property Dan Real Estate Yang Terdaftar Di Bursa Efek Indonesia Periode Tahun 2012-2015)" 39 (1): 139-47.

Islam, Rashidul, Tahsan Rahman Khan, Tonmoy Toufic Choudhury, and A.M Adnan. 2014. "How Earning Per Share (EPS ) Affects on Share Price and Firm Value How Earning Per Share ( EPS ) Affects on Share Price and Firm Value." European Journal of Business and Management 6 (17): 97106.

Kasmir. 2008. Analisis Laporan Keuangan. Jakarta: RajaGrafindo Persada.

Kurniawan, Tedy, Hafiez Sofyani, and Evi Rahmawati. 2018. "Pengungkapan Sustainability Report Dan Nilai Perusahan: Studi Empiris Di Indonesia Dan Singapura" XVI (1): 1-20.

Loh, Lawrence, Thomas Thomas, and Yu Wang. 2017. "Sustainability Reporting and Firm Value: Evidence from Singapore-Listed Companies," 1-12. https://doi.org/10.3390/su9112112.

Manisa, Dea Eka, F Defung, and Inisiatif Pelaporan Global. 2017. "The Influence of Disclosure of Sustainability Report on Financial Performance of Infrastructure Companies Listed on Indonesia Stock Exchange" 19 (2): 174-87.

Marwa, Annisa, Deannes Isynuwardhana, Annisa Nurbaiti, and Universitas Telkom. 2017. "INTANGIBLE ASSET , PROFITABILITAS , DAN SUSTAINABILITY REPORT" 9 (2): 80-88.

Mindra, Sukma, and Teguh Erawati. 2014. "PENGARUH EARNING PER SHARE (EPS), UKURAN PERUSAHAAN, PROFITABILITAS, DAN LEVERAGE TERHADAP NILAI PERUSAHAAN (Studi Kasus Pada

Economica: Jurnal Ekonomi Islam - Volume 10, Nomor 1 (2019) 
Mita Kurnia Rizki, Ratno Agriyanto, Dessy Noor Farida

Perusahaan Manufaktur Yang Terdaftar Di Bursa Efek Indonesia Pada Tahun 2009-2011)." Jurnal Akuntansi 2 (2): 10-21.

Mulyani, L, and E Pitaloka. 2017. "Pengaruh Return on Equity , Earning per Share (EPS ), Dan Debt to Equity Ratio Terhadap Price Earning Ratio ( PER ) Pada PT Indofood Sukses.” Widyakala 4 (1): 52-59.

Nurhayati, Mafizatun. 2013. "Profitabilitas, Likuiditas Dan Ukuran Perusahaan Pengaruhnya Terhadap Kebijkan Dividen Dan Nilai Perusahaan Sektor Non Jasa." Jurnal Keuangan Dan Bisnis 5 (2): 144-53.

Putri, Rafika Anggraini, and Yulius Jogi Christiawan. 2014. "Pengaruh Profatibilitas, Likuiditas, Dan Leverage Terhadap Pengungkapan Corporate Social Responsibility (Studi Pada Perusahaan-Perusahaan Yang Mendapat Penghargaan Isra Dan Listed (Go-Public) Di Bursa Efek Indonesia (Bei) 2010-2012)." Business Accounting Review 2 (1): 61-70.

Republik Indonesia. 2007. Undang-Undang No. 40 Tahun 2007 Tentang Perseroan Terbatas. Republik Indonesia, Indonesia.

Ribca, Lidya. 2009. “Analisis Nilai Akuisisi Bank Sinar Harapan Bali Menggunakan Metode Dividend Discount Model Dan Rasio Price to Book Value." Universitas Indonesia.

Ross, Stephen A. 1977. "The Determination of Financial Structure: The Incentive-Signalling Approach" 8 (1): 23-40.

Sabrin, Buyung Sarita, Dedy Takdir S, and Sujono. 2016. "The Effect of Profitability on Firm Value in Manufacturing Company at Indonesia Stock Exchange." The International Journal Of Engineering And Science 5 (10): 81-89.

Sejati, Bima Putranto, and Andri Prastiwi. 2015. "PENGARUH PENGUNGKAPAN SUSTAINABILITY REPORT.” Diponegoro Journal of Accounting 4 (1): 1-12.

Suparno, and Ristika Ramadini. 2017. "Pengaruh Intellectual Capital Dan Earning PerShare Terhadap Nilai Perusahaan ( Studi Empiris Pada Perusahaan LQ45 Yang Terdaftar Di Bursa Efek Indonesia Periode 2010-2014 )." Jurnal Manajemen Dan Keuangan 6 (1): 710-18.

Sutopo, Bambang, Sebastian Kot, Arum Kusumaningdyah Adiati, and Lina Nur Ardila. 2018. "Sustainability Reporting and Value Relevance of Financial Statements," no. 1-16. https://doi.org/10.3390/su10030678. 
Tarigan, Josua, Hatane Semuel, Universitas Kristen Petra, and Jl Siwalankerto. 2014. "Pengungkapan Sustainability Report Dan Kinerja Keuangan" 16 (2): 88-101. https://doi.org/10.9744/jak.16.2.88-101.

Velankar, Nandan, Ankita Chandani, and Amanpreet Kaur Ahuja. 2017. "IMPACT OF EPS AND DPS ON STOCK PRICE : A STUDY OF SELECTED PUBLIC IMPACT OF EPS AND DPS ON STOCK PRICE: A STUDY OF SELECTED PUBLIC SECTOR BANKS OF INDIA." International Journal of Management \& IT-Sanchayan 6 (January): 111-21.

Widyantari, Ni Luh Putu, and I Putu Yadnya. 2017. "PENGARUH STRUKTUR MODAL, PROFITABILITAS DAN UKURAN PERUSAHAAN TERHADAP NILAI PERUSAHAAN PADA PERUSAHAAN FOOD AND BAVERAGE DI BURSA EFEK INDONESIA." E-Jurnal Manajemen Unud 6 (12): 63836409.

Zak, Agnieszka. 2015. Triple Bottom Line Concept in Theory and Practice. Prace Naukowe Uniwersytetu Ekonomicznego We Wrocławiu. https://doi.org/10.15611/pn.2015.387.21. 
